\title{
Fat, oil and grease reduction in commercial kitchen ductwork: a novel biological approach
}

Article

Accepted Version

Creative Commons: Attribution-Noncommercial-No Derivative Works 4.0

Mudie, S. and Vahdati, M. (2017) Fat, oil and grease reduction in commercial kitchen ductwork: a novel biological approach. Waste Management, 61 (March). pp. 28-39. ISSN 0956-053X doi: https://doi.org/10.1016/j.wasman.2017.01.041 Available at https://centaur.reading.ac.uk/69870/

It is advisable to refer to the publisher's version if you intend to cite from the work. See Guidance on citing.

Published version at: http://dx.doi.org/10.1016/j.wasman.2017.01.041

To link to this article DOI: http://dx.doi.org/10.1016/j.wasman.2017.01.041

Publisher: Elsevier

All outputs in CentAUR are protected by Intellectual Property Rights law, including copyright law. Copyright and IPR is retained by the creators or other copyright holders. Terms and conditions for use of this material are defined in the End User Agreement.

www.reading.ac.uk/centaur

\section{CentAUR}


Central Archive at the University of Reading

Reading's research outputs online 


\title{
Fat, Oil and Grease Reduction in Commercial Kitchen Ductwork: a Novel Biological Approach
}

\author{
S. Mudie ${ }^{a^{*}}$ and M. Vahdati ${ }^{b}$
}

a Technologies for Sustainability Built Environments (TSBE) Centre, J.J Thompson Building, University of Reading, Whiteknights, Reading RG6 6AY, U.K. S.Mudie@pgr.reading.ac.uk

${ }^{\mathrm{b}}$ School of Construction Management and Engineering, University of Reading, Whiteknights, Reading RG6 6AY. U.K. M.M.Vahdati@reading.ac.uk

* Corresponding Author: Samantha Mudie

Tel.: +44 7908653596 .

Email Address: Sam.Mudie85@gmail.com

\begin{abstract}
Recent research has characterised emissions upon cooking a variety of foods in a commercial catering environment in terms of volume, particle size and composition. However, there has been limited focus on the deposition of solid grease in commercial kitchen ductwork, the sustainability of these systems and their implications on the heat recovery potential of kitchen ventilation extract air.
\end{abstract}

This paper reviews the literature concerning grease, commonly referred to as Fat, Oils and Grease (FOG) abatement strategies and finds that many of these systems fall short of claimed performances. Furthermore these technologies often add to the energy cost of the operation and reduce the potential application of heat recovery in the ventilation ductwork. The aim of this study was to develop and evaluate a novel FOG removal system, with a focus on low environmental impact.

The novel FOG removal system, utilises the biological activity of Bacillus subtilis and associated enzymes. The biological reagent is delivered via a misting system. The temperature, relative humidity and FOG deposit thickness were measured in the ductwork throughout a 3 month trial period. FOG deposit thickness was reduced by $47 \%$ within 7 weeks. The system was found to be effective at reducing the FOG deposit thickness with minimal energy cost and impact upon the kitchen and external environment. Internal ductwork operating temperature was measured with respect to future heat recovery potential and a reduction of $7^{\circ} \mathrm{C}$ was observed. 


\section{Keywords}

Grease; Commercial Kitchen; Ventilation; Ductwork; Bacillus subtilis; Sustainability.

\section{Introduction}

FOG build up in commercial kitchen ventilation ductwork has been an area of concern within the sector for many decades (Farrell et al., 2011), yet this is not reflected in the academic discourse. An extensive literature review yielded little academic work resulting in effective FOG reduction solutions within these hot and humid environments.

The increasing attention towards energy reduction, particularly in the profligate energy using environment of commercial kitchens, calls for closer consideration of the energy impacts of technologies installed in these buildings (Mudie et al., 2013). In the same vein, when considering heat recovery in commercial kitchens, there is no greater barrier to the utilisation of waste heat from kitchen ductwork than FOG deposits (CIBSE, 2009; Fisher et al., 2013). This paper introduces a novel grease reduction system against the background of what is currently known about the composition, measurement and control of FOG in commercial kitchen ducts and pays particular attention to its sustainability.

The removal of FOG from air flows also contributes to increased safety and reduction in insurance premiums. In 2005, the Building Research Establishment (BRE, UK) examined data from the London Fire Brigade and found 700 fires involving the HVAC system in London that year. Of these, the ignition of FOG within the duct represented the second largest principle cause of ventilation fires after the ventilation components. In the USA, each year grease fires result in over $\$ 100$ million dollars in direct property damage within commercial kitchens (BRE, 2005). The National Fire Protection Agency (NFPA, USA) reports that restaurants are the most at risk from fires spreading into the ductwork (23.72\% of all duct fires), and that this is due to grease build up (BRE, 2005). Improperly cleaned air may also result in unpleasant odours and greasy film deposits on neighbouring properties, and this may incur legal issues (DEFRA, 2005). Recent research has attempted to characterise emissions from cooking a variety of foods in a commercial catering environment in terms of volume, particle size and composition (Schauer et al., 1996; Gerstler et al., 1999a; Gerstler et al., 1999b; Kuehn et al., 2008; Kuehn et al., 2009a; Kuehn et al., 2009b; Fisher and Swierczyna, 2014). In general, cooking particulates are made up of hundreds of different long and short chain fatty acids, esters and carboxylic acids, several types of poly-aromatic hydrocarbons (PAHs) and lactones, among many other volatile organic compounds (VOCs) (McDonald et al., 2003; Kuehn et al., 2008; Kuehn et al., 2009a; Kuehn et al., 2009b; Abdullahi et al., 2013). 
Source apportionment is particularly challenging as species and classes of a compound are not exclusive to a particular source (Schauer et al., 1996; Schauer et al., 1999; McDonald et al., 2003; Kuehn et al., 2008). A recent review of the field concluded that while further knowledge of source-related chemical composition would be beneficial, quantitative source apportionment remains imprecise and potentially inaccurate in realistic situations with mixed cooking source types contributing to atmospheric concentrations (Abdullahi et al., 2013).

Figure 1 and Figure 2 provide examples of source-apportioned quantities and particle sizes both in the extract plume and the duct (Kuehn et al., 2008; Kuehn et al., 2009a; Kuehn et al., 2009b). In the plume, the majority of grease mass corresponded to particles larger than $10 \mu \mathrm{m}$, primarily originating from a solid fuel broiler and a wok (Kuehn et al., 2008; Kuehn et al., 2009a; Kuehn et al., 2009b). However, the majority of the grease mass emission in the ductwork was found to be in the vapour phase or associated with particles smaller than $1 \mu \mathrm{m}$ in size (Kuehn et al., 2008; Kuehn et al., 2009a; Kuehn et al., 2009b).

$$
300
$$

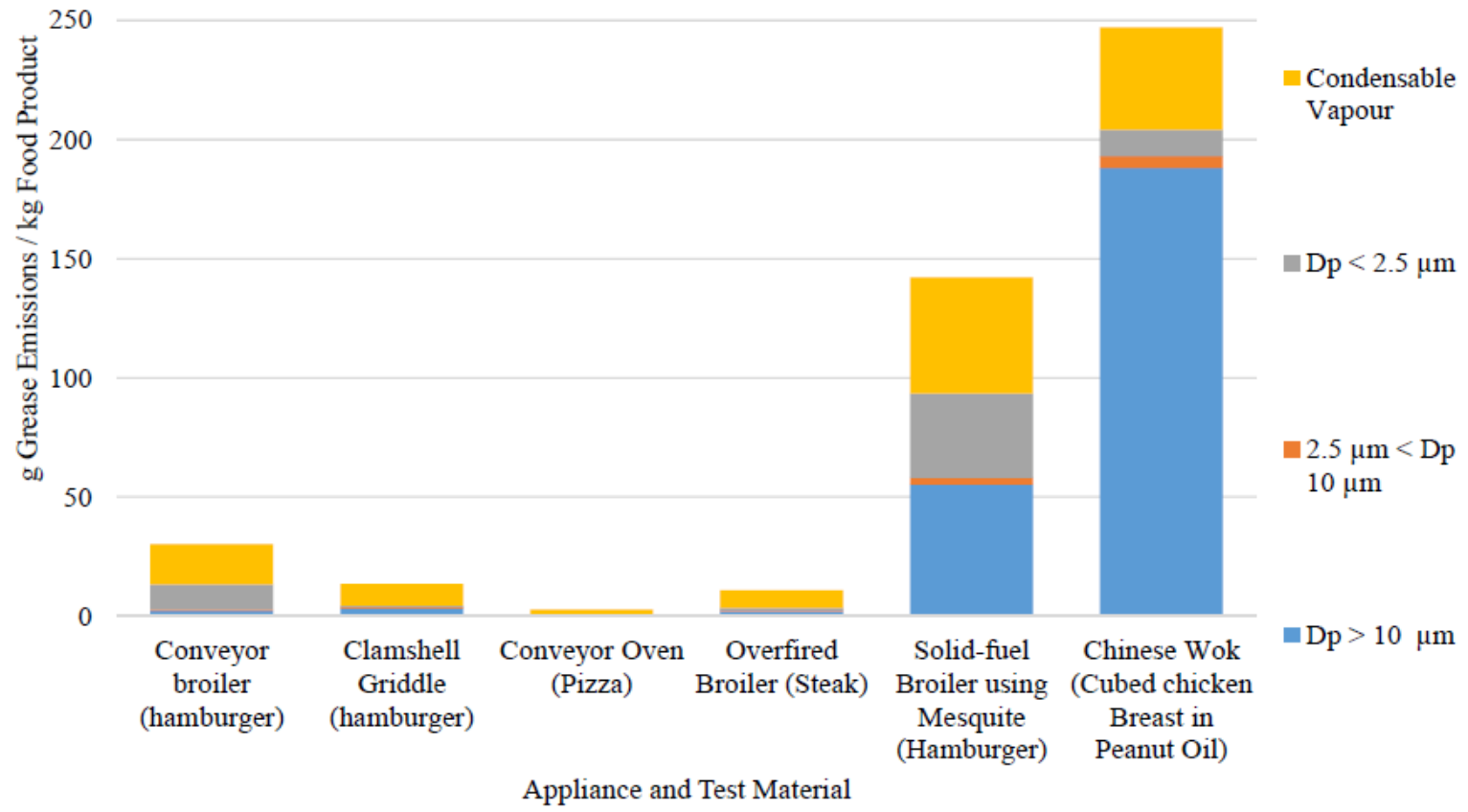

Figure 1: Average grease distribution from select appliances (plume) (adapted from Kuehn et al., 2008) 


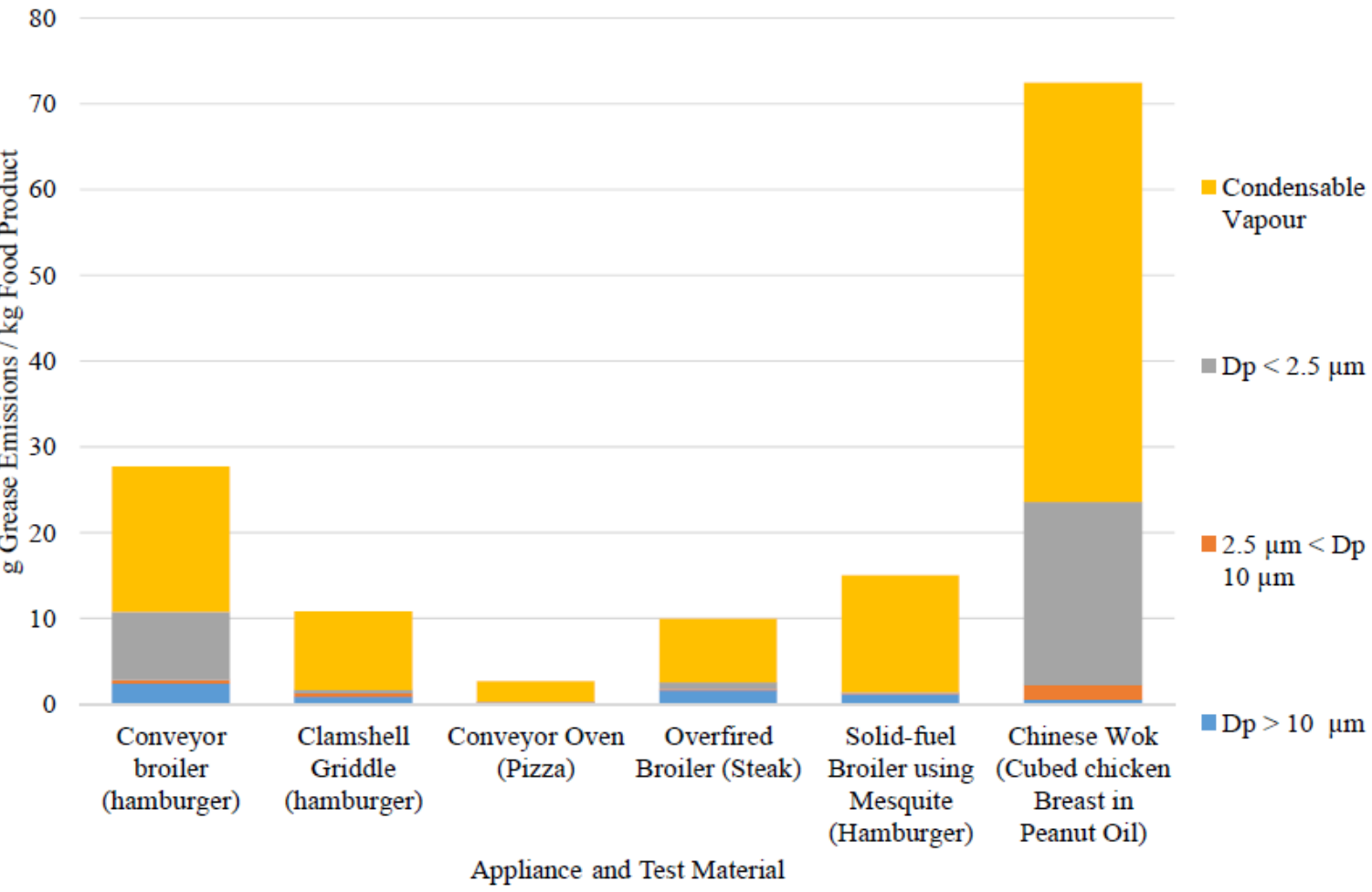

Figure 2: Average grease distribution from select appliances (ductwork) (adapted from Kuehn et al., 2008)

Gerstler et al., (1999a; 1999b; 2002) and Sippola et al., (2005) performed extensive work concerning deposition of liquid borne particles in exhaust and ventilation ducts. Gerstler et al., (2002) found that decreasing the exhaust velocity dramatically decreases the rate at which particles deposit on the wall, due to a decrease in flow turbulence. Sippola et al., (2005) concluded that deposition to duct walls and ceilings was greatly enhanced in ducts which included bends; developing turbulence was associated with greater deposition than straight ducts with fully developed turbulence. Conversely, it has also been suggested that decreasing the velocity of air flow is likely to adversely impact the indoor air quality and human exposure to pollutants (Rim and Novoselac, 2010).

Sippola et al., (2005) also found that deposition levels were greater in insulated ducts compared to uninsulated ducts. It was hypothesised that this was due to the roughness of the insulation, though this was not quantitatively explored. Nevertheless, decreasing insulation levels to reduce FOG deposition is likely to adversely impact any heat recovery potential. 


\section{Current approaches to FOG removal}

The following sections outline current methods and processes for FOG reduction used in commercial kitchens, and their viability. The UK guidance on cleanliness of ductwork states; "Total grease removal is not normally feasible", and "Due to (high levels)...the majority of the ductwork cleaning will be by manual rather than mechanical methods.” (BESA, 2013). In practice, manual cleaning may occur every 6 weeks for the heaviest loads (BESA, 2013). Anecdotal evidence suggests that sufficient care over this unpleasant and awkward task is often lacking (HSE, 2007). This can incur loss of earnings as the catering service must be shut down during cleaning, and comes at additional cost to FOG removal technologies discussed here.

\subsection{Cooking modifications}

Cooking emission rates vary by type of appliance, meat, meat-fat content, and cooking conditions such as oil and temperature (Section 1). Considering emissions factors, cooking hamburgers with $25 \%$ fat on a chargrill resulted in 15.0 (McDonald et al., 2003), 18.0 (Schauer et al., 1999), 32.7 (Norbeck, 1997) and 40.0 (Hildemann et al., 1991) g FOG/kg meat. This shows large result variation between similar experiments. Buonanno et al., (2009) found differences in emissions from the same food, cooking method and choice of oil. In the combustion of oil in general, particulate matter emissions depend on furnace temperature, combustion air temperature and $\mathrm{O}_{2}$ levels as well as other parameters. Recent research by Gao et al., (2013) found that particle emissions have little dependence on the types of vegetable oil used but have a close relationship with the heating temperature.

It is possible to reduce the fat content within the plume of extract air through refining the design of certain appliances such as grills and chargrills. Tilting grids with grease gutters directs dripping grease toward the disposal tray. Practically however, some fat on burners is desirable during chargrilling to give the characteristic taste and moisture in the food. Furthermore, these strategies are not robust enough to deliver the reduction in grease levels required for heat recovery or conform to recommendations set out in TR 19 as evidenced by the common need for manual ductwork cleaning (BESA, 2013).

\subsection{Ventilation effectiveness}

Several peer-reviewed articles identify ventilation effectiveness as an indicator of particle distribution, but these tend to focus on particulate pollutants, $\mathrm{CO}$ and $\mathrm{CO}_{2}$ in a room and human exposure rather than cleanliness of ductwork (Rim and Novoselac, 2010; Saha and Guha, 2012). Decisions regarding the design and use of kitchen exhaust hoods for controlling contaminants require consideration of energy costs in addition to indoor air quality (Cao et al., 2014; Rim et al., 2012). There is contradicting evidence to suggest that the lower fan speeds and 
corresponding air flow rates may both reduce (CIBSE, 2009) and conversely enhance (Gerstler et al., 1999a; Gerstler et al., 1999b) the ability of the extract system to vent all cooking effluent from the ductwork.

The use of demand controlled ventilation (DCV) is increasingly common in commercial kitchens as it is often regarded as the single largest step a kitchen operator can take to reduce energy demand and running costs (CIBSE, 2009). In some instances, energy cost savings from DCV can be 30-50\% (CIBSE, 2009). Indicators for variable fan speed drives may include air or cooking surface temperature, steam, $\mathrm{CO}_{2}$ or cooking effluent itself (for example, a via piezoelectric transducer (Liu and Young, 2002). Increasing ventilation rate to more effectively capture FOG particles mitigates energy savings from DCV (Fisher and Swierczyna, 2014). Amending the canopy, ductwork or overall ventilation design incurs large capital cost, restricting these strategies as retrofit solutions in practice. These approaches may also be viewed as moving the issue downstream to the environment, where growing public and regulatory concern is building with regard to air quality.

\subsection{Air filters}

Particle filtration may be provided via washable or disposable filters to include lamb's wool, mesh, baffle and cartridge filters. CIBSE state that Panel, Bag and HEPA type filters reduce airborne smoke particles down to 0.3 $\mu \mathrm{m}$ (CIBSE, 2009), however ASHRAE studies found grease particles $<1 \mu \mathrm{m}$ (and some above $10 \mu \mathrm{m})$ are not captured (Kuehn et al., 2008; Kuehn et al., 2009a; Kuehn et al., 2009b; Welch and Kuehn, 2005). Confirming this, Farrell et al., (2011) found filtration will only capture solid and liquid phase particles and not gas phase emissions. ASHRAE RP-1151 concluded that while some manufacturers claim FOG removal efficiencies of 95\%, actual efficiencies of 30\% - 60\% are found (Welch and Kuehn, 2005).

Grease filters are relatively easy to clean and maintain and have a low capital cost (DEFRA, 2005). However, these filters may create $<500 \mathrm{~Pa}$ additional resistance to the air flow, adding to the electrical load of the fans (CIBSE, 2009). Grease filters need to be replaced regularly but anecdotal evidence suggests that this is not carried out to a satisfactory standard. The high operating cost and environmental impact of filter disposable to landfill should be considered as well as their inability to deal with odours. Disposable filters contribute to higher insurance premiums as they may be considered a fire risk. Due to these issues, DEFRA recommends against their use (DEFRA, 2005). 


\subsection{Electrostatic precipitators (ESPs) and adsorption filters}

Efficiencies of 90-99\% are reported for ESPs and activated carbon filters (DEFRA, 2005), however, effectiveness is limited to grease that adheres to smoke or adsorption surfaces. Pre-filters are required upstream of these devices to provide protection from large contaminants, resulting in airflow resistance and increased fan power. These systems require weekly cleaning and maintenance schedules and regular replacement with high associated cost (DEFRA, 2005). These systems are less effective at relative humidity (RH) $>75 \%$ and at high temperatures $\left(>60^{\circ} \mathrm{C}\right.$ ESPs and $>40^{\circ} \mathrm{C}$ adsorption systems). For this reason they are often ineffective in the typical range of environmental conditions within a commercial kitchen duct. ESPs consume large quantities of energy in their continuous operation (CIBSE, 2009).

\subsection{Water filtration}

Water wash canopies spray or mist hot or cold water and detergent around the extraction system chamber. These systems are effective, efficient and have the added benefit of reducing fire risk. They cannot be overloaded and are low maintenance, but they are expensive to install and require hot and cold water supplies as well as drainage. High operating cost is also reported due to (often continuous) water usage throughout their operation. These systems also contribute to high pressure drops within the duct and decreased air temperature, adverse to heat recovery (DEFRA, 2005).

\subsection{UV-C lamps and ozone systems}

Ultraviolet light breaks down FOG via light (photolysis) and ozone (ozonolysis). An experimental study by Farrell et al., (2011) found close to $0 \%$ capture efficiency from a range of UV systems, even with added protective filtration. The study found that the residence times and ducting length were not sufficient to drive organic chemical reactions to completion.

A further issue with respect to the use of UV and ozone systems is safety. The breakdown of FOG via ozonolysis can lead to the production of many undesirable compounds including nitrogen oxides, aldehydes (including formaldehyde) and of course, excess ozone (Weschler et al., 2006). Even in low concentrations these are linked with negative health implications (WHO, 2005). Gaskets in the air handling unit and other rubber materials will deteriorate when exposed to such high ozone concentrations over long periods of time (Ekberg and Woollett, 2013).

The addition of UV at least doubles the ventilation systems capital cost and significantly increases its maintenance and running costs; useful radiation output of the UV bulbs is reduced by a relatively small quantity 
of cooking effluent covering the bulb (Farrell et al., 2011). The high energy consumption of UVC should be considered, as should the negative implications upon health and safety upon maintaining UVC bulbs (CIBSE, 2009). While UV lamps create negligible additional resistance, significant protective filtration does contribute to pressure drops and therefore increased energy input to the fans.

\subsection{FOG removal utilising biological and chemical activity}

Outside of FOG removal within extract air, there exists a number of biological abatement approaches utilising bacteria and enzymes (microbial lipases, proteases and amylases). These are currently attracting enormous attention in industry and academia due to their specificity and the detailed understanding of their nature (Hasan et al., 2009). Enzymes are already used for the digestion of grease within "grease traps" installed inside floor and sink drains in commercial kitchens and other FOG producing premises, to prevent the clogging of pipework and to adhere to environmental regulation.

Industrial enzymes are utilised in biological laundry detergents, industrial processes such as the removal of lubricants in textile processing, in waste water treatment (Hasan et al., 2009; Macrae and Hammond, 1995) and in surface cleaning applications (Valentinia et al., 2012). A series of studies investigated the use of a compact rockwool biofilter inoculated with Bacillus in eliminating emissions from commercial cooking extract air (Andersson-Chan, 2000). Using a live working kitchen, it was found that grease aerosols were effectively removed. However, sampling of the filter after one year revealed that the moisture content and bacterial numbers were very low. This was due to the high velocities of air drying out the material. The high deposition of these hydrophobic compounds in the filter bed lowered the $\mathrm{pH}$ and hindered the transfer of water, substrate, and oxygen. High pressure drops also developed over the loose rockwool filter material, thus lowering the outflow from the kitchen and restaurant (Andersson-Chan, 2000).

\section{Measurement of deposit thickness and associated regulation}

As this study focuses upon examining solid deposition over time, the important work of ASHRAE in developing a method to characterise airborne cooking effluent (ASTM Standard F2519 (ASTM, 2015; Schrock and Knappmiller, 2015)), as well as technologies such as such as Tapered Element Oscillating Microbalance (TEOM) and piezocrystals were disregarded.

Ramesh (2010) investigated methods of film thickness measurement for the application of grease surface deposit assessment and stated that very little work has been performed in this area. Table 1 summarises the current methods for measurement of existing deposit thickness. 
Table 1: Summary of deposit thickness measurement methods

\begin{tabular}{|c|c|c|c|}
\hline Method & Description & Accuracy & Source \\
\hline $\begin{array}{l}\text { Deposit } \\
\text { Thickness Test } \\
\text { (DTT) }\end{array}$ & $\begin{array}{l}\text { Electromagnetic induction thickness gauge with a } \\
\text { non-contact measuring tip. }\end{array}$ & $\pm 3 \mu \mathrm{m}$ & (BESA, 2013) \\
\hline $\begin{array}{l}\text { Dust Vacuum } \\
\text { Test (VT) }\end{array}$ & $\begin{array}{l}\text { Air pumped at } 10.0 \text { litres/min in the void of a } \\
\text { template placed on the ducts surface. May only } \\
\text { be used for dry surfaces, fans must not be } \\
\text { running. }\end{array}$ & $\pm 5 \%$ & (BESA, 2013) \\
\hline $\begin{array}{l}\text { Wet Film } \\
\text { Thickness Test } \\
\text { (WFTT) }\end{array}$ & $\begin{array}{l}\text { Toothed comb (typically used to measure paint } \\
\text { thickness). Tracks left by the tooth of the comb } \\
\text { upon scraping the surface are examined. }\end{array}$ & $\pm 5 \mu \mathrm{m}$ & (BESA, 2013) \\
\hline $\begin{array}{l}\text { Capacitive } \\
\text { sensors }\end{array}$ & $\begin{array}{l}\text { The sum of the conductivity measurements from } \\
\text { internal and external sensors. }\end{array}$ & $\begin{array}{l} \pm 0.012 \\
\mu \mathrm{m}\end{array}$ & $\begin{array}{l}\text { (Lion Precision Ltd, } \\
\text { 2013; MTI } \\
\text { Instruments Inc, 2013) }\end{array}$ \\
\hline $\begin{array}{l}\text { Laser } \\
\text { technologies }\end{array}$ & $\begin{array}{l}\text { Compact sensor heads placed on either side of the } \\
\text { duct whereby sub-pixel calculations are able to } \\
\text { calculate thickness. }\end{array}$ & $\pm 20 \mu \mathrm{m}$ & (Omron, 2013) \\
\hline
\end{tabular}

In the UK, the TR-19 "Cleanliness of Ventilation Systems - Guide to Good Practice” outlines the testing procedures that may be used in establishing the cleanliness of ductwork. The Building Engineering Services Association (BESA) (formerly the Heating and Ventilation Contractors Association (HVCA)) Ventilation Hygiene Group recommends the Deposit Thickness Test (DTT - hard baked long standing deposits), Wet Film Thickness Test (WFTT) or the Vacuum Test (VT) (BESA, 2013).

Table 2 provides cleaning recommendations for deposit thickness levels taken after extensive field tests. These are levels consistent with good practice (not regulations), other factors such as cooking methods and potential ignition sources will affect the risk of fire and odour. 
Table 2: Surface deposit limits (DTT) upon inspection (BESA, 2013)

\begin{tabular}{|l|l|}
\hline Surface contaminant limits & Description \\
\hline $200 \mu \mathrm{m}$ mean across the system & Complete cleaning required \\
\hline Any single measurement above $500 \mu \mathrm{m}$ & Urgent local cleaning required \\
\hline
\end{tabular}

A minimum of three test points per system is required, with no less than one test point per 50 linear meters of ducting up to 300 linear meters, and no less than one test point per 100 linear meters thereafter. An average must be calculated across the system.

\section{Materials and methods}

The objective of the experimental program was to determine if biological agents could reduce the FOG deposits on an already soiled duct, and prevent the further build-up of FOG during operation.

\subsection{Trial Site, ducting and extraction system}

The novel system was trialled at a live working restaurant in Hampshire, South East England. The site was selected due to its known frequent requirement for manual duct cleaning. The FOG reduction strategy previously employed by the site was five in-hood single-stage, baffle-type lamb's wool filters. Despite these filters, the site employed 4-6 manual cleans per year (Figure 3).
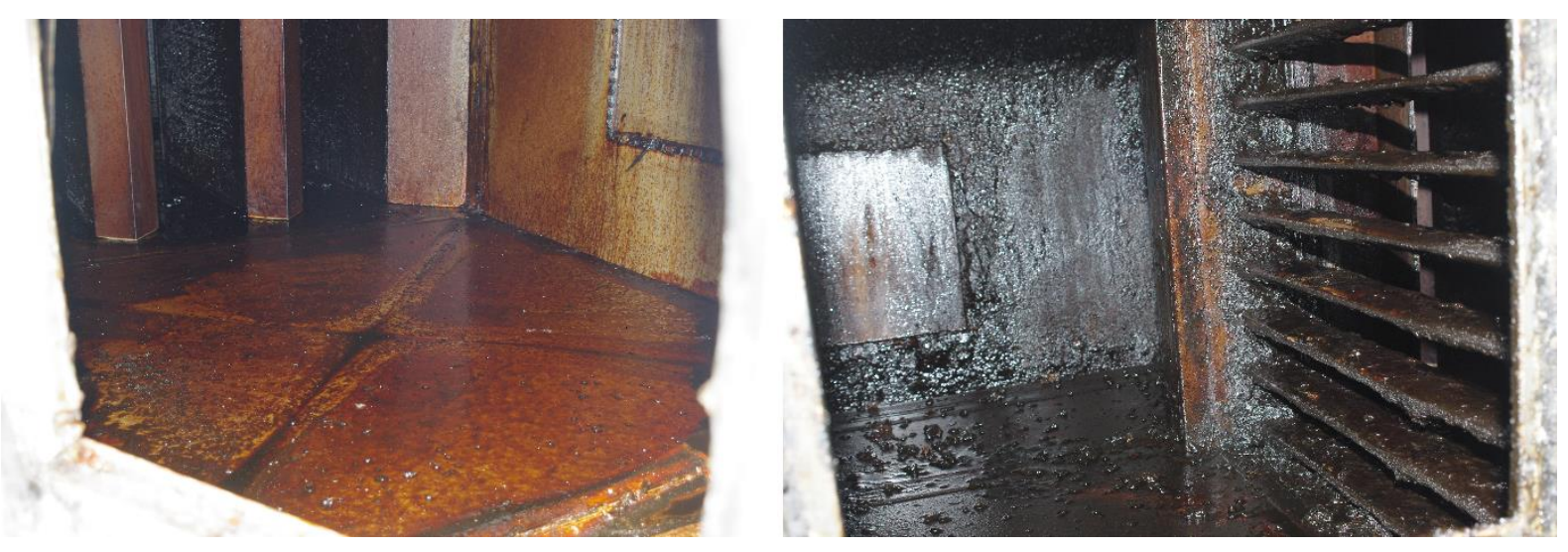

Figure 3: Trial site ventilation duct interior 3 weeks post manual duct clean

The site is a grill-led business serving a multitude of grilled meats such as steaks, burgers and chicken at an average of 373 meals per day during the trial period. 
The extract system comprises of two local closed-end exhaust hoods serving two gas chargrills (1187 mm and $1535 \mathrm{~mm}$ wide), two single basket and one twin basket electric fryers, a 6-burner gas range with oven and a wall mounted electric sandwich grill. These hoods along with 4 spigots, duct exhaust air to the $8.73 \mathrm{~m}$ long galvanised steel ducting situated upon the first floor roof of the restaurant. The air then exits through the exhaust chimney to the surrounding atmosphere. Figure 4 shows the layout of the duct on the roof of the site and the location of its twelve access hatches.

The ventilation system employs a Cheetah ${ }^{\mathrm{TM}}$ demand controlled system. The DCV consists of a number of intelligent modules which are interconnected by a data communications network. The system modules include a display processor with system power supply and override facility, a sensor processor, a data logger with GPRS remote access system, temperature sensors (located in ducting) and optical sensors detecting smoke and steam (located in extract hood). Air flow meters in ducts and carbon dioxide sensors are also included as optional modules.

With the DCV operating in normal mode, the system's sensors control the fans. The fans are set to a minimum speed by default but automatically increase in the event of smoke, high temperatures in ducts, low air flow in ducts and high levels of carbon dioxide in the kitchen. Since DCV was installed at the trial site, energy savings of $37 \%$ have been found. The typical ventilation rate is $6.12 \mathrm{~m}^{3} / \mathrm{s}$.

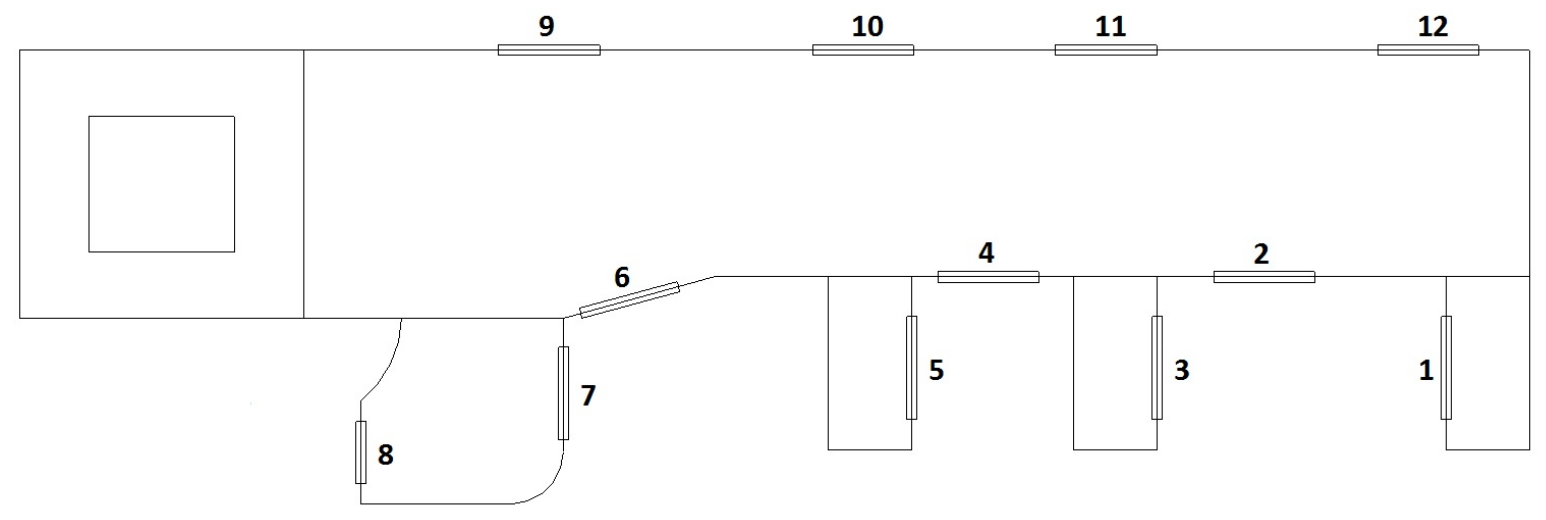

Figure 4: Duct plan view from above including access hatch numbers (not to scale)

\subsection{The novel system}

Figure 5 shows a schematic diagram of the novel FOG control system. The system introduces a fine mist of micro droplets ( $1 \mu \mathrm{m}$ diameter) of an environmentally friendly biological formula into the commercial kitchen extraction and ventilation system. The biological formula is stored in a vessel and mixed with mains water (2.5 
bar) at a 1:15 ratio with the use of a pump and solenoid valve in a self-contained central unit. The mixture is then pumped through a high pressure feeding pipe to the extraction hood and ducting where 19 nozzles spray the reagent around the ducting and hood. The nozzle feeding pressure is 55 bar.

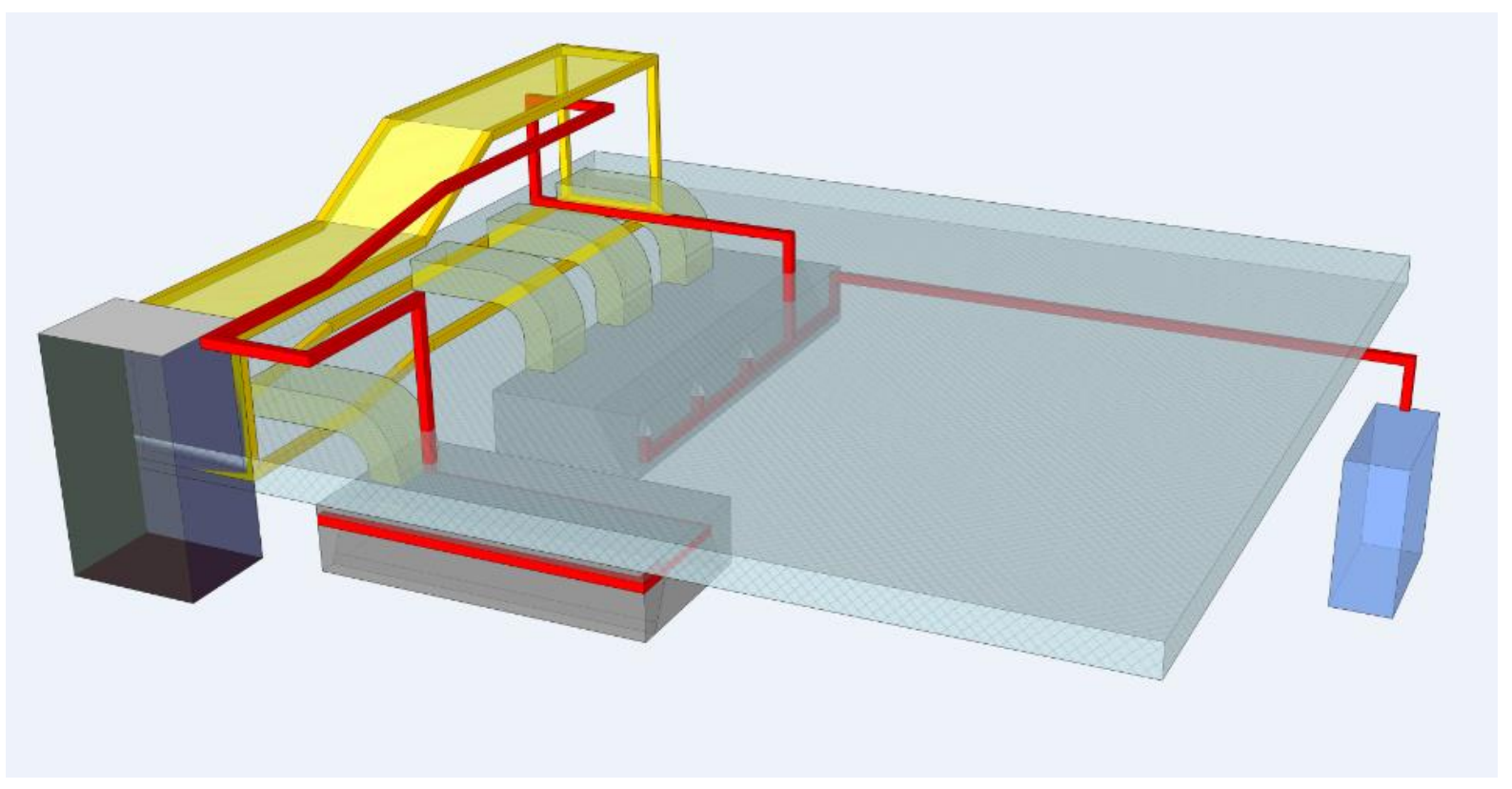

Figure 5: Novel system and test duct layout (not to scale)

The dosing regime is regulated by the DCV system. When the DCV system senses that the extract fans require speeding up during cooking activity (by way of temperature detection and an optical laser detecting cooking vapour/steam), the reagent is sprayed into the duct for 2 minutes and repeated after 5 minutes. During periods of low cooking activity, the reagent is sprayed for 1 minute, every 8 minutes. The dosing regime is able to be varied and set remotely. The system was inspected for conformance to a number of building, fire, health and safety regulations by the appropriate local authorities during operation.

\subsection{Biological reagent}

For use in ventilation ductwork, it is necessary to achieve bacterial growth in the mesophilic range, whereby bacteria will grow between $10-45^{\circ} \mathrm{C}$. There is often a relationship between growth rate, temperature, $\mathrm{pH}$ and enzyme production (Bonala and Mangamoori, 2012).

The organism, Bacillus subtilis, is of substantial commercial interest due to its highly efficient protein secretion system of lipases, proteases and amylase, and its high substrate specificity. B. Subtilis is particularly well suited to this application as the duct environment is oxygen rich and exists within the ideal conditions of the microorganism. The ideal temperature is between 25 and $35^{\circ} \mathrm{C}$, with $35^{\circ} \mathrm{C}$ often noted as the optimum 
temperature for aerobic microorganisms (Swanson and Loehr, 1997; Winer and Leson, 1991). Microorganisms capable of degrading VOCs show optimum growth at pH values between 6 and 8 (van Lith et al., 1997; Winer and Leson, 1991).

The bacteria, procured from GSEnvironnement, were kept in spore form (to resist their environment and prolong their lifespan), by surrounding spores with biocides and salt. The spores are activated upon dilution with water in the ideal environment and with an abundant source of nutrient. A surfactant is added to create the required mix of phases. This also permits some initial breakdown of FOG deposits allowing the bacteria (which is contained within the water phase) to mix adequately with the substrates.

A compromise was reached between a larger droplet size for increased moisture to activate spores, and a smaller droplet size to increase surface area coverage while reducing the water use in the system. This thereby increases the sustainability when compared to other water based FOG reduction systems.

The system was examined for Legionella risk under BS 6068-4.12:1998 (BSI, 1998). In accordance with the European Council Directive 2000/54/EC, the reagent consortium was subjected to testing for toxin production and risk of exposure, and designated as "Class 1" (EC, 2000). It is not considered pathogenic, nor hazardous and therefore no special precautions are necessary during its use, besides good hygiene practice.

\subsection{Experimental methods}

Upon assessment of the available methods to monitor grease deposition thickness (Table 1), the DTT method was selected due to its accuracy, ease of use and its recommendation in the HVCA regulation and guidance notes; no cleaning of the probe is required between samples and no delays due to laboratory tests would ensue. The methods used in this study are summarised in Table 3.

Table 3: Kitchen, ductwork and system monitoring

\begin{tabular}{|l|l|l|}
\hline Data & Method & Frequency and location \\
\hline thickness & $\begin{array}{l}\text { An Elcometer 456 Duct Deposit Measuring System was } \\
\text { selected to measure grease thickness. The Elcometer 456 } \\
\text { has been specifically designed to meet the requirements } \\
\text { of the Deposit Thickness Test (DTT) in Building } \\
\end{array}$ & $\begin{array}{l}\text { Spigots are assigned numbers } \\
\text { Engineering Services Association (BESA) Guide to }\end{array}$ \\
\hline
\end{tabular}




\begin{tabular}{|c|c|c|}
\hline & $\begin{array}{l}\text { Good Practice for the measurement of dust and grease } \\
\text { deposits within ventilation systems and kitchen ducts } \\
\text { made of ferrous metals (BESA, 2005). } \\
\text { Elcomaster Version } 2.0 \text { software is employed to } \\
\text { summarise the readings taken. }\end{array}$ & $\begin{array}{l}\text { were recorded inside spigots } \\
1,3,5 \text { and } 8 \text {. } \\
\text { The recommended Elcometer } \\
\text { template was utilised; } 20 \\
\text { measurements were taken at } \\
\text { each location providing } 80 \\
\text { readings per day from the } \\
\text { four locations. }\end{array}$ \\
\hline $\begin{array}{l}\text { Relative } \\
\text { humidity (RH) }\end{array}$ & $\begin{array}{l}\text { Relative humidity meter EL-USB-2 }{ }^{+} \text {from Lascar } \\
\text { Electronics with Easylog USB Version 6.8.0.0 software. }\end{array}$ & $\begin{array}{l}1 \text { minute intervals in the duct } \\
\text { interior at spigot } 8 \text { for two } \\
\text { weeks prior to the trial and } \\
\text { continuously during the trial. }\end{array}$ \\
\hline Temperature & $\begin{array}{l}\text { Temperature meter EL-USB-2+ from Lascar Electronics } \\
\text { with Easylog USB Version 6.8.0.0 software. }\end{array}$ & $\begin{array}{l}1 \text { minute intervals in the duct } \\
\text { interior at spigot } 8 \text { for two } \\
\text { weeks prior to the trial and } \\
\text { continuously during the trial. }\end{array}$ \\
\hline $\begin{array}{l}\text { DCV electricity } \\
\text { consumption }\end{array}$ & $\begin{array}{l}\text { Electricity use of extract and supply fans monitored with } \\
\text { SPMAX current transformer logger (Three phase and } \\
\text { power factor). }\end{array}$ & Constantly monitored. \\
\hline $\begin{array}{l}\text { Enzymatic } \\
\text { system } \\
\text { electricity use }\end{array}$ & $\begin{array}{l}\text { Electricity use of enzymatic system (using SP Max } \\
\text { loggers on the compressor and pump supply cables). }\end{array}$ & Every minute. \\
\hline $\begin{array}{l}\text { Enzymatic } \\
\text { system water } \\
\text { use }\end{array}$ & $\begin{array}{l}\text { Portable ultrasonic water meter and logger (B Meter } \\
\text { GSD5). }\end{array}$ & Every day, at 6:00am. \\
\hline
\end{tabular}




\begin{tabular}{|c|c|c|}
\hline $\begin{array}{l}\text { Enzymatic } \\
\text { system reagent } \\
\text { volume used }\end{array}$ & $\begin{array}{l}\text { Manually measuring, monitoring and recording levels of } \\
\text { reagent in supply vessel. }\end{array}$ & Every day, at 6:00am. \\
\hline Air flow & A calibrated digital anemometer (TID 1309). & $\begin{array}{l}\text { Air flow rate is measured in } \\
\text { the hood. }\end{array}$ \\
\hline $\begin{array}{l}\text { Ventilation } \\
\text { Effectiveness }\end{array}$ & $\begin{array}{l}\mathrm{CO}_{2} \text { levels and temperature in the kitchen environment } \\
\text { are measured with a Testo } 435 \text { probe to ensure } \\
\text { ventilation effectiveness throughout the trial. } \\
\text { Testo Comfort Software x } 35 \text { V } 3.4 \text { is utilised. }\end{array}$ & $\begin{array}{l}\text { Three fixed location in the } \\
\text { centre of the cook line, } 2 \mathrm{~m} \\
\text { above the ground in } \\
\text { accordance with IGEM/UP/19 } \\
\text { (IGEM, 2014). }\end{array}$ \\
\hline
\end{tabular}

A paired t-test was used for comparing the mean FOG layer thickness over four sampling sites within the duct on day 1 of study compared with the final day of the trial. All statistical analyses were conducted using SPSS v.21. A p-value $<0.05$ was considered statistically significant.

A repeated measures ANOVA was fitted on the weekly average FOG thickness per hatch using a first order auto-regressive heterogeneous covariance structure with study week as a fixed effect.

\subsection{Microbiological activity testing}

A range of laboratory tests were considered to meet the study aim. However, it is important to bear in mind that conditions in batch laboratory flasks differ greatly from the real world setting. Therefore, a number of in-situ tests were carried out on duct microflora with, and without the novel system use by utilising a similar reference site. The reference site was of similar set up (the same brand of restaurant containing similar appliances, similar location (Hampshire, South East England) and similar number of meals served per day).

Total viable count (TVC) was performed enabling identification of colony forming units at the trial site and reference site. $1 \mathrm{~g}$ of recovered solid from the duct surface was dissolved in a recovery medium and serially diluted before inoculation of nutrient agar plates. Colonies were counted and expressed as number of bacterial colonies per gram of recovered solid. Colonies were also examined microscopically to confirm the species.

Total FOG, total protein and $\mathrm{pH}$ were determined for the trial site and the reference site. $25 \mathrm{~g}$ of solids were obtained from the duct surface and subjected to solvent extraction (iso-octane) to recover the FOG, evaporate 
the solvent and weigh the total recovered FOG as a $\%$ of the original. Total organic Nitrogen was measured by the Kjeldahl (titration) method to infer total protein (bacterial) content.

\section{Results and discussion}

\section{1 $\quad$ FOG deposit thickness}

The level of FOG deposit at each of the four measurement locations was found to decrease over the duration of the experimental period. The initial average thickness of $1239 \mu \mathrm{m}$ was reduced by $47 \%$ to an average of $668 \mu \mathrm{m}$ in 51 days. The average deposit thickness was determined from the 20 measurements at each location per day to provide an average for that location per day. The averages of each of the four locations were again averaged to provide the total FOG deposit thickness for the duct on each day as per DTT (Figure 6).

\subsection{0}

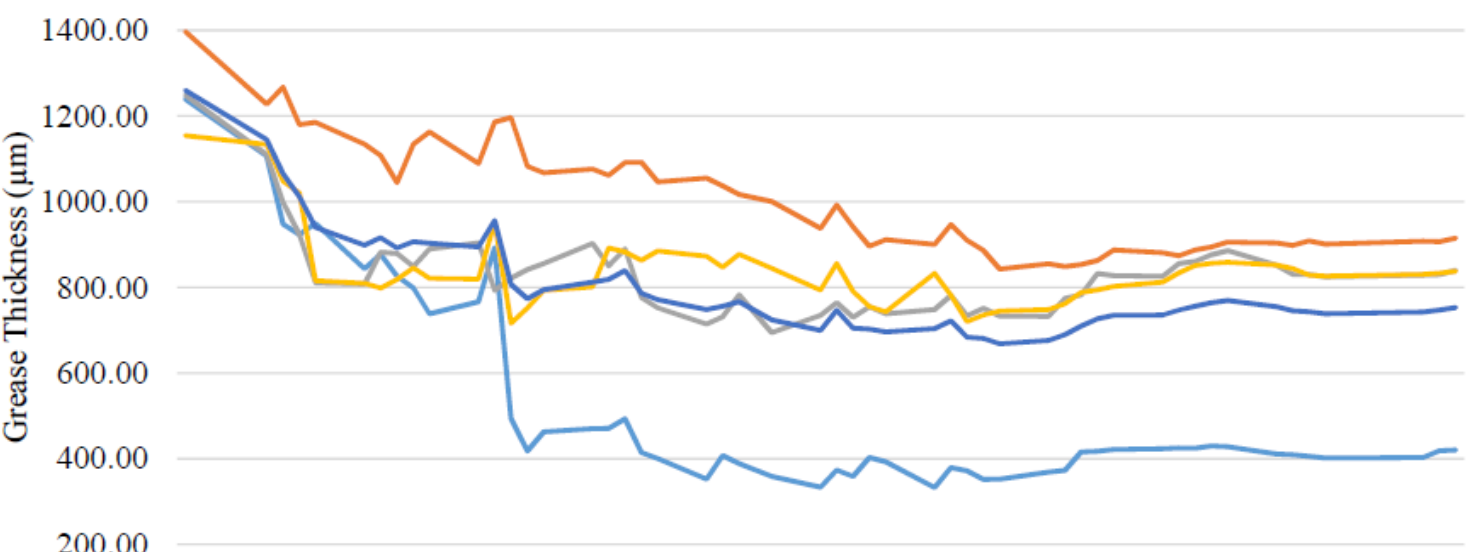

200.00

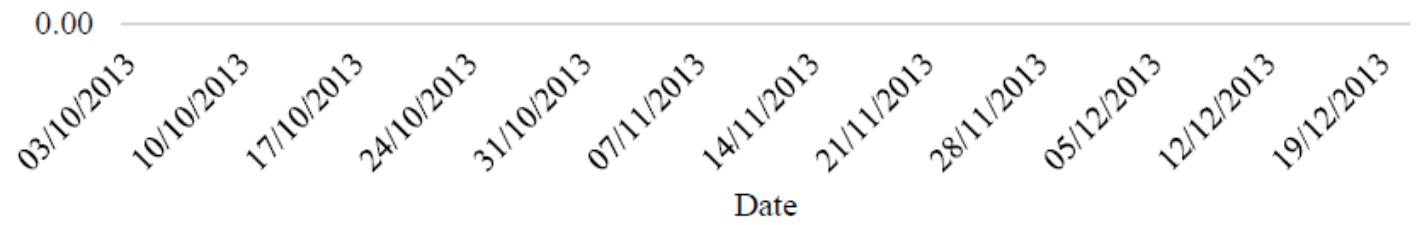

- Hatch 1 - Hatch 3 - Hatch 5 - Hatch 8 - Average

Figure 6: FOG deposit thickness $(\mu \mathrm{m})$

The most striking results were found in Hatch 1 which saw reductions of $887 \mu \mathrm{m}$ (72\%) from $1239 \mu \mathrm{m}$ to $352 \mu \mathrm{m}$

(Figure 7). More marked reduction in this location is due to the fact that this end of the duct is situated above a microwave combi oven which emits less particulates than the gas fired chargrill, which was situated under Hatch 8 (the least affected hatch location). 

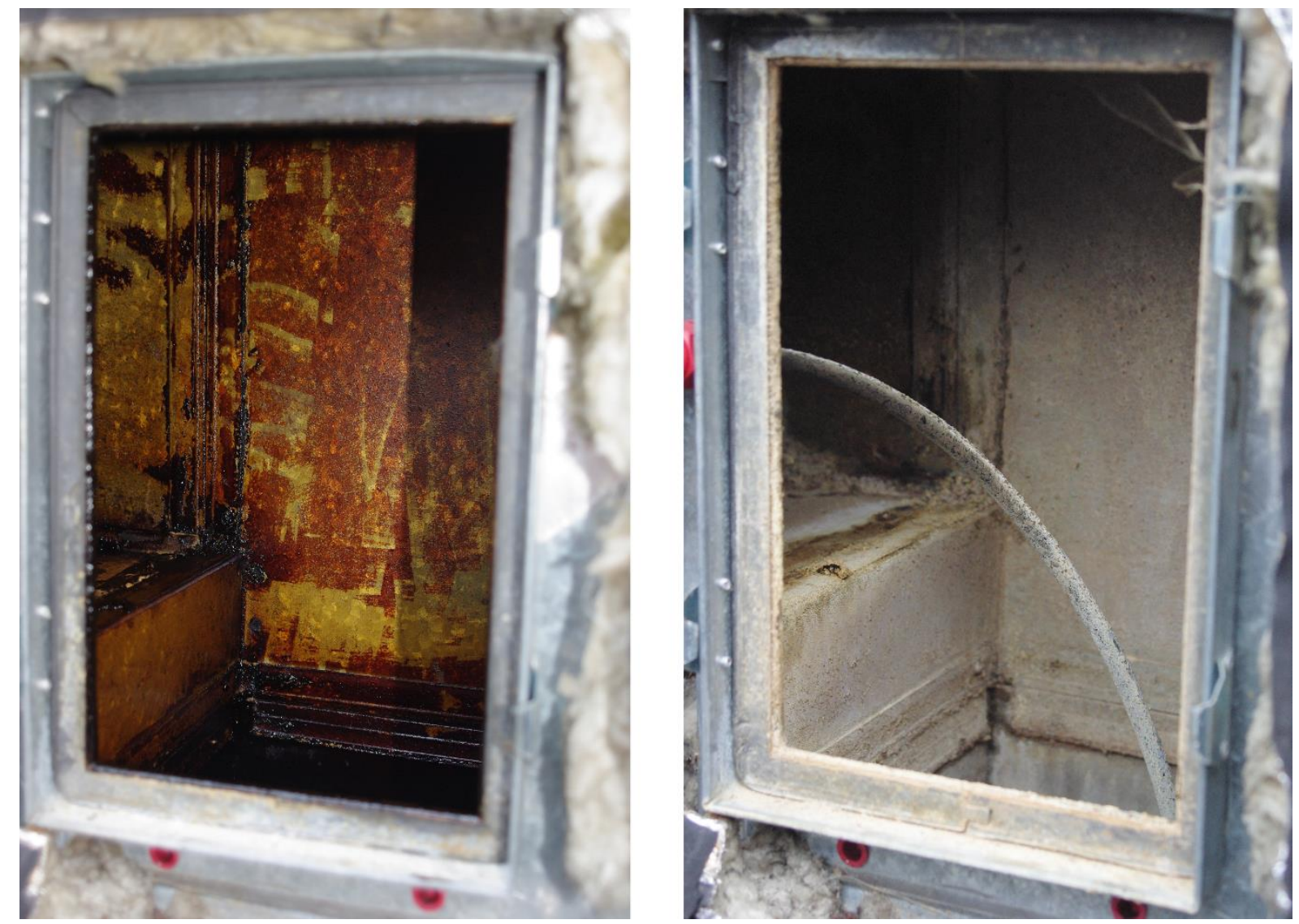

Figure 7: Hatch 1 pre-installation (left) and 2 months post-installation (right)

A summary of the trial results is presented in Table 4 .

Table 4: Summary of FOG reduction results and statistics

\begin{tabular}{|c|c|c|c|c|c|c|}
\hline $\begin{array}{l}\text { Trial } \\
\text { Day }\end{array}$ & Location & $\begin{array}{l}\text { Mean FOG deposit } \\
\text { thickness }(\mu \mathrm{m})\end{array}$ & $\begin{array}{l}\text { Overall Duct } \\
\text { Mean }\end{array}$ & $\begin{array}{l}\text { Standard } \\
\text { Deviation }\end{array}$ & $\begin{array}{l}\text { Coefficient of } \\
\text { Variation (\%) }\end{array}$ & Date \\
\hline \multirow[t]{4}{*}{ Day 1} & Hatch 1 & 1239.45 & \multirow[t]{4}{*}{1260.05} & 252.35 & 20.36 & \multirow[t]{4}{*}{$03 / 10 / 2013$} \\
\hline & Hatch 2 & 1397.40 & & 152.36 & 10.90 & \\
\hline & Hatch 3 & 1248.95 & & 228.40 & 18.29 & \\
\hline & Hatch 4 & 1154.4 & & 290.08 & 25.13 & \\
\hline \multirow[t]{2}{*}{ Day 6} & Hatch 1 & 1106.95 & \multirow[t]{2}{*}{1144.75} & 195.80 & 17.69 & \multirow[t]{2}{*}{$08 / 10 / 2013$} \\
\hline & Hatch 2 & 1227.75 & & 202.11 & 16.46 & \\
\hline
\end{tabular}




\begin{tabular}{|c|c|c|c|c|c|c|}
\hline & Hatch 3 & 1110.4 & & 249.77 & 22.49 & \\
\hline & Hatch 4 & 1133.9 & & 273.98 & 24.16 & \\
\hline Day & Hatch 1 & 351.95 & 681.2 & 132.80 & 37.73 & $21 / 11 / 2013$ \\
\hline & Hatch 2 & 886 & & 262.96 & 29.68 & \\
\hline & Hatch 3 & 751.15 & & 271.20 & 36.10 & \\
\hline & Hatch 4 & 735.7 & & 221.30 & 30.08 & \\
\hline Day & Hatch 1 & 352.4 & 668.325 & 135.99 & 38.59 & $22 / 11 / 2013$ \\
\hline & Hatch 2 & 842.75 & & 276.80 & 32.84 & \\
\hline & Hatch 3 & 733.1 & & 299.60 & 40.87 & \\
\hline & Hatch 4 & 745.05 & & 194.09 & 26.05 & \\
\hline
\end{tabular}

Figure 6 shows a tailing off of FOG reduction rate around $670 \mu \mathrm{m}$, where deposits did not significantly increase or decrease for the last 3 weeks of the trial. This plateau is a steady state where the quantity of time and bacteria was insufficient to combat the older FOG layers, but were sufficient to prevent further build up. An "all-in-one" solution such as the reagent used during this trial, containing bacteria as well as detergents and surfactants has an inherent compromise. Too much detergent degrades the cell walls of the bacteria. Not enough, and there is not the required initial chemical breakdown of the grease and adequate mixing of phases. This is the reason for the tailing off of the FOG deposit reduction. Additionally, the deeper into the grease layer, the more the FOG deposits are expected to have been hard baked onto the surface, requiring extra work to remove.

A simple paired t-test comparing the first and last day of study found a p-value of 0.019 indicating that the FOG thickness reduction was significant to $95 \%$ confidence interval. Overall the study week had a significant effect on FOG reduction with a p-value of $<0.001$. Mean FOG thickness decreased continuously throughout study. From week six, the significance of the reduction increased, and remained as a highly significant reduction throughout the remainder of the study (Table 5). 
Table 5: FOG reduction and significance by study week

\begin{tabular}{|c|c|c|c|c|c|c|c|}
\hline \multirow[t]{2}{*}{$\begin{array}{l}\text { (A) Study } \\
\text { Week }\end{array}$} & \multirow[t]{2}{*}{$\begin{array}{l}\text { (B) Study } \\
\text { Week }\end{array}$} & \multirow{2}{*}{$\begin{array}{l}\text { Mean } \\
\text { Difference } \\
\text { (A-B) }\end{array}$} & \multirow[t]{2}{*}{ Std. Error } & \multirow[t]{2}{*}{$\mathrm{df}$} & \multirow[t]{2}{*}{ Sig.** } & \multicolumn{2}{|c|}{$\begin{array}{l}95 \% \text { Confidence Interval } \\
\text { for Difference } * *\end{array}$} \\
\hline & & & & & & $\begin{array}{l}\text { Lower } \\
\text { Bound }\end{array}$ & $\begin{array}{l}\text { Upper } \\
\text { Bound }\end{array}$ \\
\hline 2 & 1 & $-109.608^{*}$ & 20.884 & 3.055 & .013 & -175.396 & -43.820 \\
\hline 3 & 1 & -183.485 & 73.422 & 2.493 & .105 & -446.473 & 79.503 \\
\hline 4 & 1 & -219.386 & 75.022 & 2.772 & .068 & -469.651 & 30.880 \\
\hline 5 & 1 & $-275.601 *$ & 59.820 & 3.531 & .013 & -450.768 & -100.434 \\
\hline 6 & 1 & $-301.490^{*}$ & 45.120 & 8.553 & .000 & -404.377 & -198.603 \\
\hline 7 & 1 & $-326.005^{*}$ & 42.139 & 24.287 & .000 & -412.921 & -239.089 \\
\hline 8 & 1 & $-292.965^{*}$ & 42.300 & 15.959 & .000 & -382.656 & -203.274 \\
\hline 9 & 1 & $-253.970^{*}$ & 45.554 & 20.728 & .000 & -348.781 & -159.159 \\
\hline 10 & 1 & $-269.846^{*}$ & 47.990 & 19.986 & .000 & -369.956 & -169.736 \\
\hline 11 & 1 & $-264.760^{*}$ & 50.146 & 18.721 & .000 & -369.822 & -159.698 \\
\hline
\end{tabular}

*.The mean difference is significant at the .05 level.

** Adjustment for multiple comparisons: Least Significant Difference (equivalent to no adjustments).

Data were gathered on the number of meals served each day between each measurement of FOG thickness.

Preliminary data analysis revealed no relationship between number of meals and grease reduction, confirming that the significant reduction in FOG levels was independent of the number of meals cooked (Figure 8).

Therefore, no additional analysis was required. 


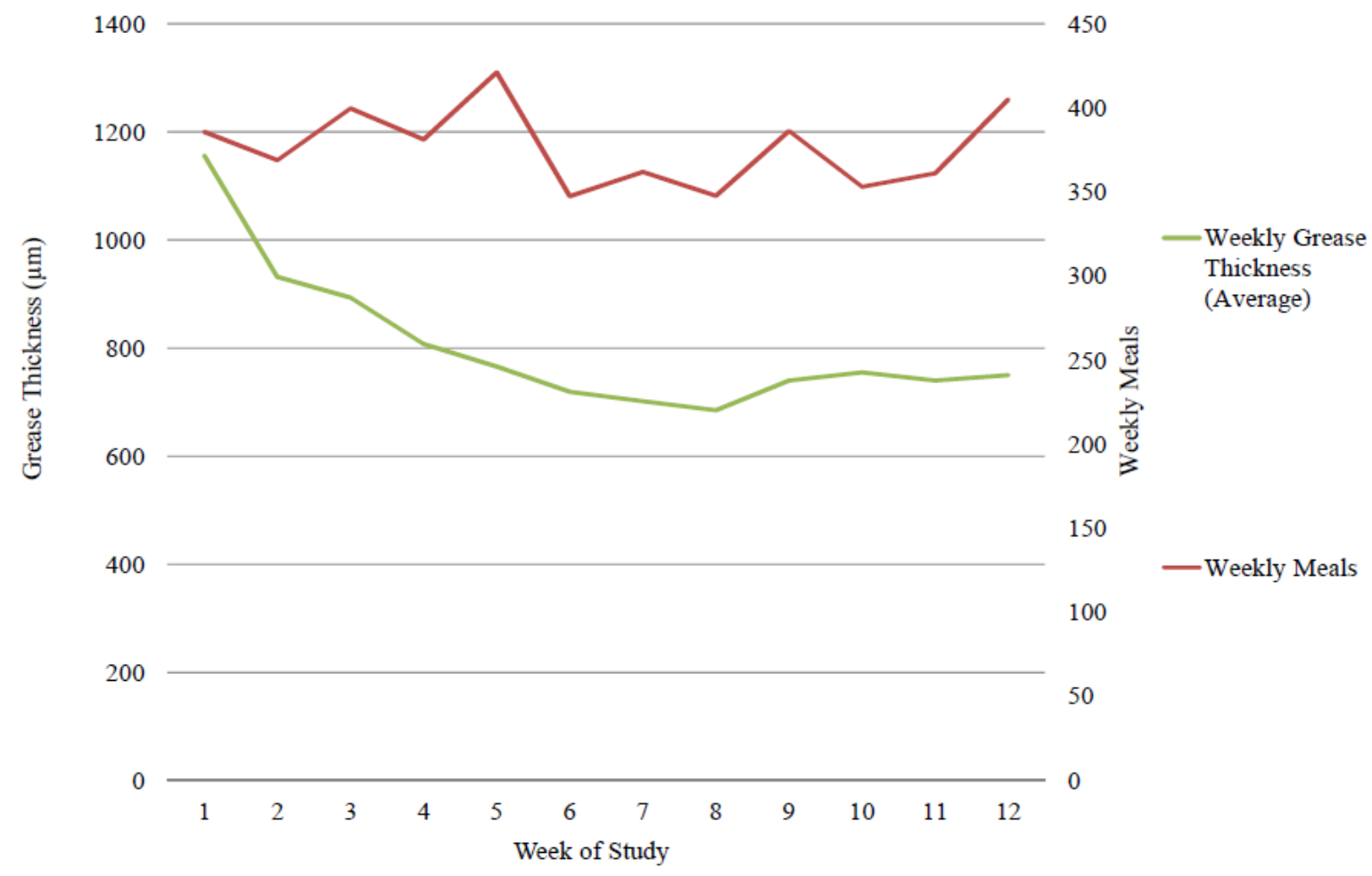

Figure 8: Average FOG thickness and number of meals served

\subsection{Biological reagent tests}

Total viable count (TVC) was performed at the trial site and at a reference site of similar set up. The results are displayed in Table 6.

Table 6: Results of total viable count study

\begin{tabular}{|l|l|}
\hline Location & Colony forming units per gram (cfu/g) solids \\
\hline Trial site & $5 \times 10^{7}$ \\
\hline Reference site & $<10$ \\
\hline
\end{tabular}

At the trial site, the bacteria recoverable in solids were found be of high number. Subsequently, these colonies were subjected to microscopic examination and found to be Gram positive and catalase positive rods. This confirmed them as exclusively bacteria originally injected into the duct during treatment (B. subtilis). When a site is not employing the novel system, the duct will contain little to no natural microflora. The duct setting is certainly an environment conducive to the growth of B. Subtilis. 
Total FOG, total protein and $\mathrm{pH}$ were determined from sample material from the trial site and reference site ductwork. The results are presented in Table 7.

Table 7: Microbiological performance at the trial and reference site

\begin{tabular}{|l|l|l|l|}
\hline Location & Total FOG $(\mathrm{g} / 100 \mathrm{~g}$ & Total Protein $(\mathrm{g} / 100 \mathrm{~g}$ & $\mathrm{pH}$ \\
& solids $)$ & solids $)$ & \\
\hline Trial site & $11.9(15 \%)$ & 6.40 & 5.2 \\
\hline Reference site & 81.8 & 2.80 & 5.3 \\
\hline
\end{tabular}

The amount of protein in solids recovered from treated ducting is 3-fold higher than for untreated ducting. Thus, $90 \%$ of solids recovered from the duct at the trial site is bacterial biomass, which is derived from bacterial cell protein and not food residues.

As shown in Table 7, approximately $12 \%$ of the total solids recovered at the trial site were found to be FOG compared to over $80 \%$ at the reference site. This demonstrates that treatment is capable of reducing FOG load in ducting by $85 \%$. The table also shows that the $\mathrm{pH}$ is lower than optimal in both of the ducts, and should ideally be increased to neutral.

\subsection{Kitchen environment, ventilation efficacy and DCV energy use}

The internal kitchen environment was monitored to ensure that the ventilation system remained effective in terms of ventilation rate inferred by $\mathrm{CO}_{2}$ levels and direct measurement of air flow. The measured airflow $(6.12$ $\mathrm{m}^{3} / \mathrm{s}$ ) exceeds the theoretical minimum airflow calculated via method 1 , standard DW/172 (BESA, 2005) of $3.77 \mathrm{~m}^{3} / \mathrm{s}$. The ventilation efficacy during the trial is also inferred by the absence of any automatic shutdown due to the gas interlocking valve. As this did not occur, the pressure within the duct was maintained above minimum levels and the ventilation rate remained effective.

The $\mathrm{CO}_{2}$ levels within the kitchen were measured as a final check that the ventilation system remained effective. In accordance with IGEM/UP/19 (IGEM, 2014), as no single $\mathrm{CO}_{2}$ measurement exceeded the critical limit of 2800ppm (an average of $638 \mathrm{ppm}$ was found), the extract system may be considered as working effectively throughout the novel system trial, keeping $\mathrm{CO}_{2}$ levels far below the maximum permitted. 
Figure 9 shows the energy savings of the DCV ventilation system. Average daily energy use of the fans during operating hours (9:00-23:00) prior to the installation of the DCV system was $150 \mathrm{kWh}$ compared with $95 \mathrm{kWh}$ post installation, providing a saving of $37 \%$.

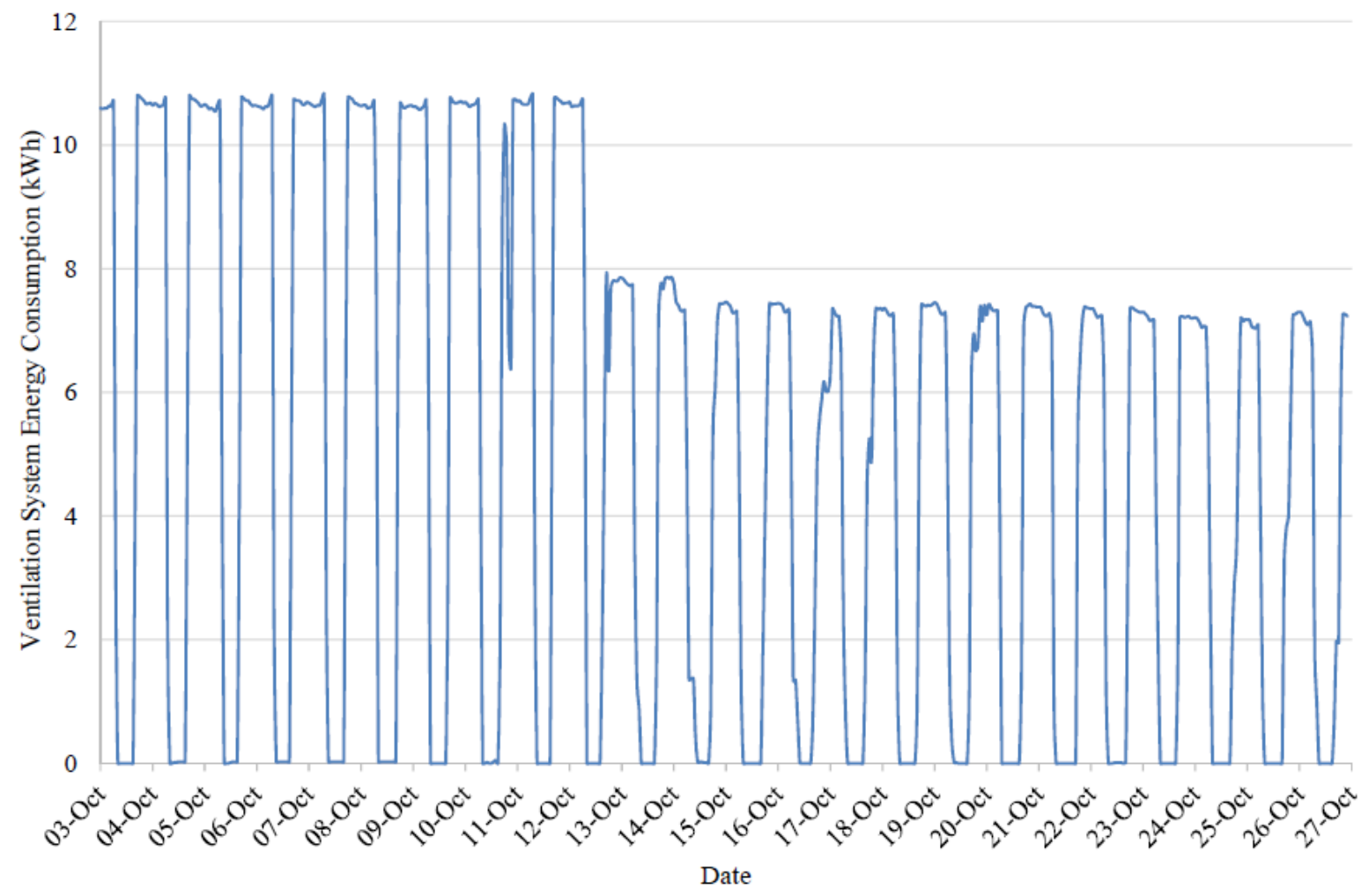

Figure 9: DCV energy consumption $(\mathrm{kWh})$ and savings

\subsection{Duct environment}

Figure 10 shows a sample of the internal duct environment (RH and temperature) for three days in the week prior to the novel system installation compared with the same three days two weeks into the experimental system trial period. 


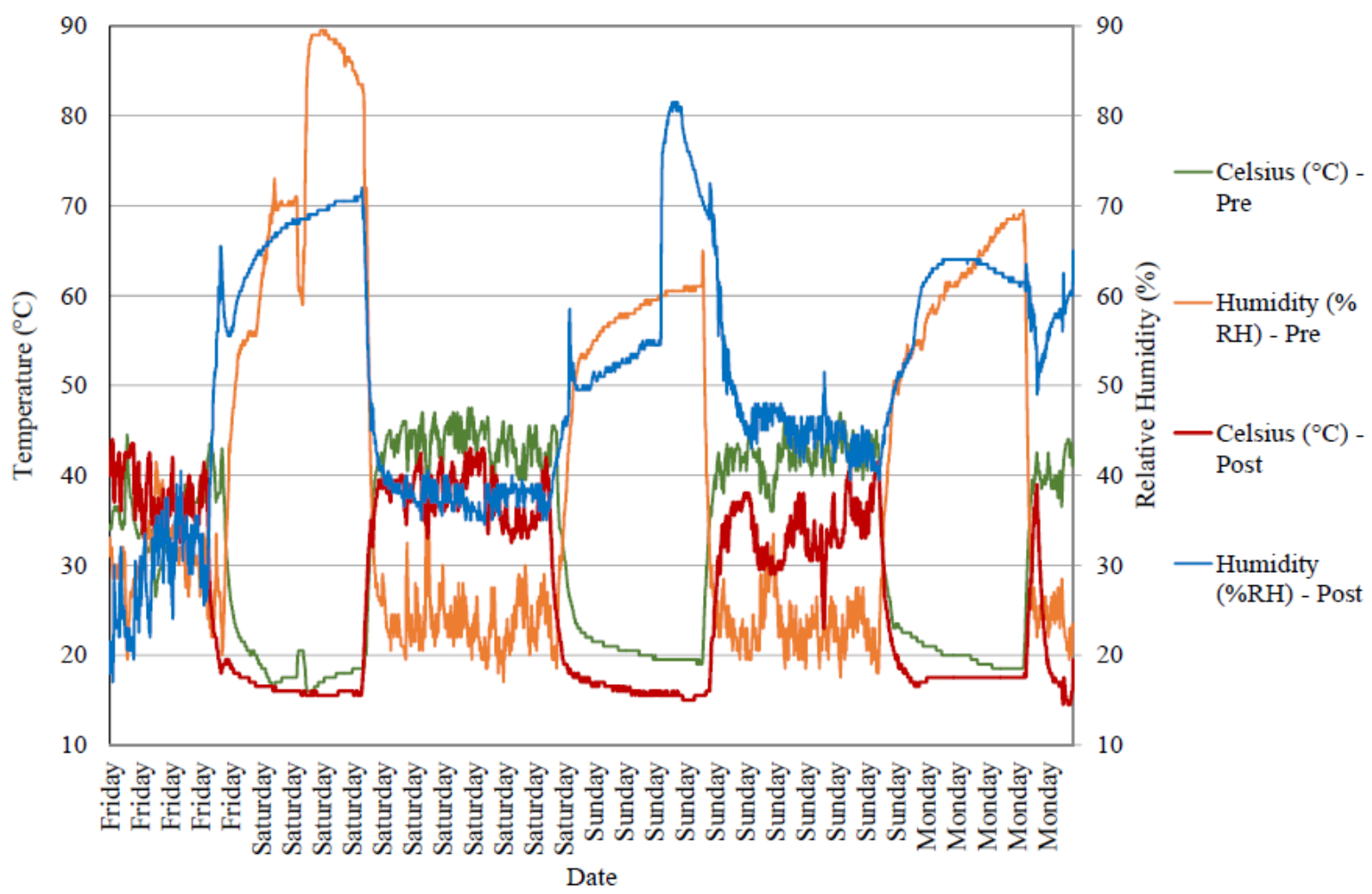

Figure 10: Duct environment pre and post installation

As this is a live working business, differences in the humidity and temperature can be due to the type, timing and volume of food served on each day and can also be affected by the fluctuating external environmental conditions. However, given that DCV is employed in this facility, and that meals served during each of these periods were fairly consistent, results are most likely to be due to the installation and running of the novel system.

As expected, Figure 10 shows a slight average temperature drop during hours of operation of $7^{\circ} \mathrm{C}$ for the post installation compared with pre installation duct environment. An increase in $\mathrm{RH}$ for the post system installation compared with pre-installation was also observed. These results are to be expected when injecting cold water into the duct. Table 8 summarises the maximum and average temperatures of the pre and post installation internal duct environment during kitchen operating hours (9:00-22:30).

Table 8: Summary of maximum and average temperature and relative humidity during operating hour's pre and post installation

\begin{tabular}{|l|l|l|l|l|}
\hline Period & Average & Average Relative & Maximum & Maximum Relative \\
& Temperature $\left({ }^{\circ} \mathrm{C}\right)$ & Humidity $(\% \mathrm{RH})$ & Temperature $\left({ }^{\circ} \mathrm{C}\right)$ & Humidity $(\% \mathrm{RH})$ \\
& & & & \\
\hline
\end{tabular}




\begin{tabular}{|l|l|l|l|l|}
\hline Pre-installation & 41 & 25 & 52 & 83 \\
\hline Post-installation & 34 & 45 & 48 & 78 \\
\hline
\end{tabular}

\subsection{Utilities consumption and sustainability}

The water and electricity use of the system were monitored throughout the trial to allow comparison of results with other available FOG abatement methods in terms of cost and overall sustainability. A two week sample of the water and electricity use is displayed in Figure 11.

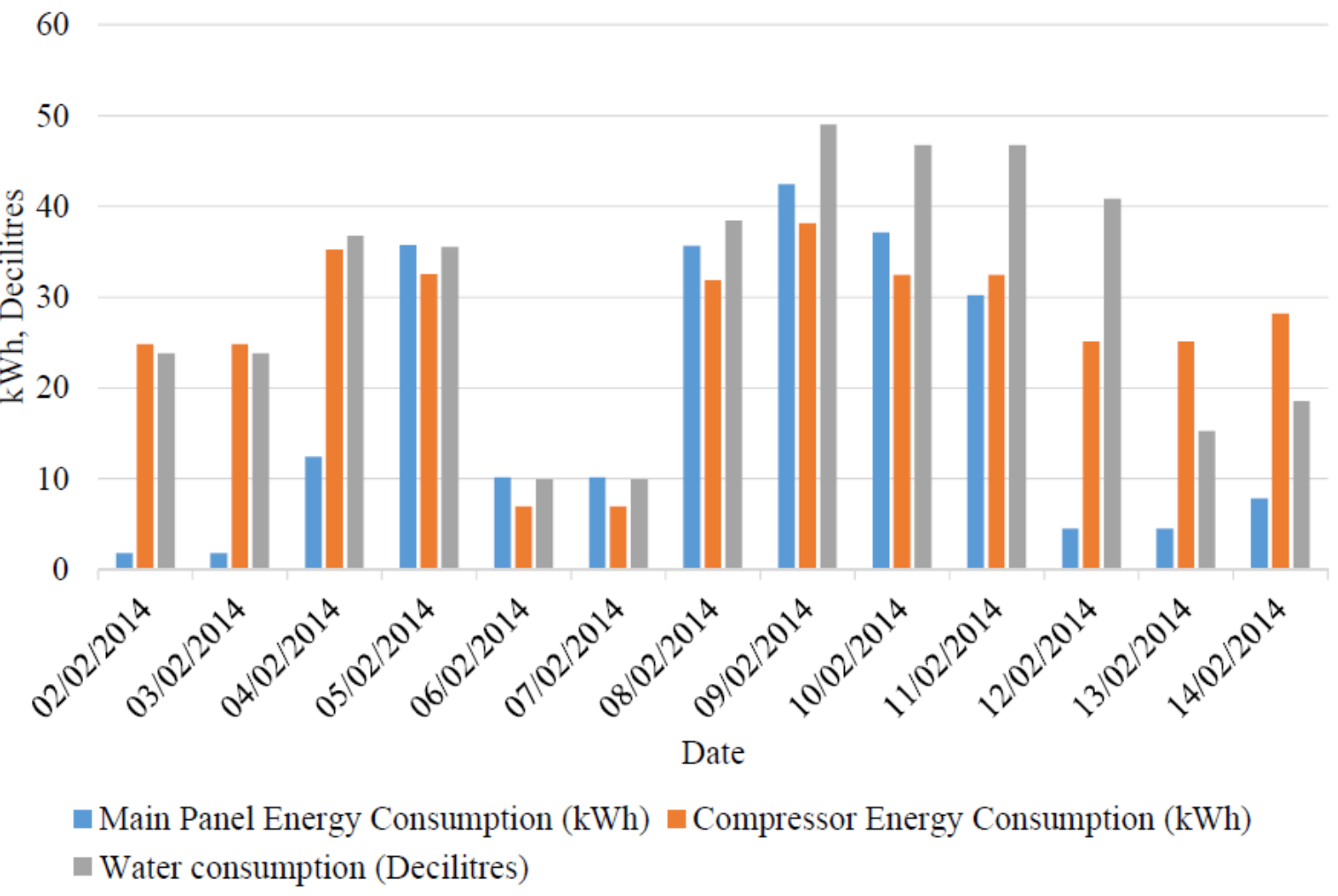

\section{Figure 11: Novel system utilities consumption}

The cost of the electricity used in the novel system (main panel and compressor) was found to be an average of $3.49 \mathrm{kWh}$ per day. In terms of water use, a daily average of 16.85 decilitres $\left(1.69 \mathrm{dm}^{3}\right)$ was found. Avoiding the use of non-sustainable filters mitigates significant waste to landfill and the associated charges from the operator's perspective. 


\section{Conclusions and further work}

In response to the issues presented by current FOG reduction technologies, a novel system utilising a reagent containing Bacillus subtilis was trialled in situ, during normal kitchen operation. Experimental data and implications of this study are particularly industrially relevant.

Direct FOG deposit thickness measurement and microflora activity tests confirm that the novel system reduces FOG deposits in commercial kitchen ductwork by $47 \%$ in seven weeks. The system mitigates build-up of FOG, even if it cannot yet remove the older, more persistent layers of soiling to the suggested limits posed by the BESA of $200 \mu \mathrm{m}$.

Further work is required in dosing strategies to assess the minimum amount of reagent required to effectively clean while still retaining minimum levels of waste and some demand control. The method of application also requires further investigation as a "fog" rather than a mist or spray may give better retention of reagent against substrate. The levelling off of the rate of FOG deposit reduction might be avoided by injecting the surfactant/detergent mix separately to the microbiological mix to allow for a stronger chemical clean whilst not affecting spore germination. The biological solution could be pre-incubated and active bacteria dosed into the system. The existing, older FOG deposits may be more effectively removed in this way, or by a manual clean upon installation.

The average duct temperature dropped by $7^{\circ} \mathrm{C}$ once the novel system was installed. The RH increased by an average of $20 \%$, however the maximum temperature and humidity remained similar. This could potentially reduce the effectiveness of heat recovery, but it is unlikely that this would be as dramatic as a continuous water jet system. Temperature reduction may be further minimised using warmer water. Pre-incubation of the bacteria may reduce the impact of water temperature upon air temperature. Accessing recovered heat from the cleaner air could eventually evolve into a closed loop system with pre-heating achieved by heat recovered from the duct itself.

Though some attempt was made to assess the novel FOG mitigation system in terms of operational cost and sustainability, it is very challenging to compare different ventilation and FOG systems in different kitchens because of equipment used, food produced, duct factors, turbulence etc.

The system is highly adaptable to a great variety of kitchens. Types and sources of FOG deposits are highly variable, however it is possible to tailor the biological mixture to a certain degree towards the likely FOG make 
up. For example, restaurants serving more marinated meats are likely to incur a higher sugar content in their FOG deposits. The reagent might therefore contain a higher proportion of sugar eating bacteria. Conversely, capsicum extracts have been found to inhibit the growth of certain bacteria, so consequently, restaurants serving a more spicy mix of foods might tailor their microbiological reagent accordingly (Dorantesa et al., 2000).

By design, the novel system avoids reliance on staff operation. There is no health and safety issue posed by ozone or harmful light as is the case with UV systems. Addition of an inhibitor to avoid any possible pit corrosion upon galvanised steel surfaces and use of a water softener or filter to avoid limescale build up may be added when required. Further advantages of the novel system presented in this paper include reduced insurance costs for kitchen operators, as the system may lessen the risk of fire, both by reduction of flammable deposits and as a fire fighting resource. Furthermore, addition of essential oils and fragrance into the reagent may contribute to further solving the odour issues experienced by commercial kitchen operators and their neighbours.

\section{Funding}

This work was supported by the Engineering and Physical Sciences Research Council [grant number EP/G037787/1]

\section{Acknowledgement}

Special thanks must be made to Mitchells \& Butlers plc, James Sharman, Richard Felgate, David Fielding, Dr. Neil Smith, Sue Wyeth-Price and Quintex Ltd (particularly Peter Evans, James Drake and Simon Jarman), without whom this study would not have been possible.

\section{References}

Abdullahi KL, Delgado-Saborit JM, Harrison RM. Emissions and indoor concentrations of particulate matter and its specific chemical components from cooking: A review. Atmos Environ 2013; 71: 260-294.

Andersson-Chan A. A Rockwoll Biofilter for the Treatment of Restaurant Emissions. PhD thesis, Architecture and Water, Department of Civil, Environmental and Natural Resources Engineering, Luleå Unviersity of Technology: 2000. 
ASTM. Standard Test Method for Grease Particle Capture Efficiency of Commercial Kitchen Filters and Extractors (Standard F2519), American Society of Heating, Refrigerating and Air-Conditioning Engineers, Inc (ASHRAE) Atlanta: 2015.

BESA, TR 19 - Guide to Good Practice Internal Cleanliness of Ventilation Systems. Building Engineering Services Association (BESA), London, UK: 2013.

BESA. Standard for kitchen ventilation systems DW/172. Building Engineering Services Association (BESA), London, UK: 2005b.

Bonala KC, Mangamoori LN. Production and Optimization of Lipase from Bacillus tequilensis NRRL B-41771. Int. J Biotechnol Appl 2012: 4(1): p. 134-136.

BRE, Examination of the Fire Resistance Requirements for Ducts and Dampers. Building Research Establishment. (BRE), UK; 2005.

BSI, Water quality. Microbiological methods. Detection and enumeration of Legionella. BS 6068 -4.12:1998, ISO 11731:1998. British Standards Institution (BSI), UK; 1998

Buonanno G, Morawska L, Stabile L. Particle emission factors during cooking activities. Atmos Environ 2009; 43(20): 3235-42.

Cao G, Awbi H, Yao R, Fan Y, Siren K, Kosonen R et al. A review of the performance of different ventilation and airflow distribution systems in buildings. Build Environ 2014; 73: 171-86.

CIBSE. TM50 - Energy Efficiency in Commercial Kitchens. 1st ed. The Chartered Institution of Building Services Engineers (CIBSE) London; 2009.

DEFRA, Guidance on the Control of Odour and Noise from Commercial Kitchen Exhaust Systems. HM Government Department for the Environment, Food and Rural Affairs (DEFRA), London; 2005.

Dorantesa L, Colmenero R, Hernandeza H, Motab L, Jaramilloa ME, Fernandez E, et al. Inhibition of growth of some foodborne pathogenic bacteria by Capsicum annum extracts. Int J Food Microbiol 2000: 57(1-2): p. 12528.

EC, The protection of workers from risks related to exposure to biological agents at work. 2000/54/EC. European Council (EC); 2000 
Ekberg L, Woollett J. Ozone Treatment of Extract Air from a Restaurant Kitchen with Heat Recovery in CLIMA 2013 Proceedings: Prague, Czech Republic: 2013

Farrell FM, Thomas TM, Bicking, MKL. Analysis of Chemical and Physical Effects of Ultraviolet Bulbs on Cooking Emissions. J Air Waste Manag Assoc 2011; 61(10): 1005-14.

Fisher D, Swierczyna R, Karas A. Future of demand-controlled ventilation for commercial kitchens. ASHRAE J 2013; 55(2): 48-54.

Fisher D, and Swierczyna, R. 90.1 and Designing High Performance Commercial Kitchen Ventilation Systems. ASHRAE J 2014; 56(11): 12-24.

Gao J, Cao C, Zhang X, Luo Z. Volume-based size distribution of accumulation and coarse particles (PM .0.110) from cooking fume during oil heating. Build Environ 2013; 59: 575-80.

Gerstler W. New Rules For Kitchen Exhaust. ASHRAE J 2002; 11: 26-31.

Gerstler WD, Kuehn TH, Pui DYH, Ramsey JW, Rosen M, Carlson RR, Petersen SD. Identification and characterization of effluents from various cooking appliances and processes as related to optimum design of kitchen ventilation systems. ASHRAE RP-745, Phase 2 Final Report. American Society of Heating, Refrigerating and Air Conditioning Engineers, Inc (ASHRAE) Atlanta: 1999b.

Gerstler, WD, Kuehn TH, Pui DYH, Ramsey JW, Doerr MP. Identification and characterization of effluents from various cooking appliances and processes as related to optimum design of kitchen ventilation systems. ASHRAE RP-745, Phase 1 Final Report. American Society of Heating, Refrigerating and Air Conditioning Engineers, Inc (ASHRAE) Atlanta: 1999a.

Hasan F, Shah AA, Hameed A. Industrial Applications of Microbial Lipases. Enzyme Microb. Technol 2006; 39: $235-51$.

HSE (UK), Gas safety in catering and hospitality. Catering Information Sheet 23. Health and Safety Executive (HSE). Merseyside, UK: 2007.

Hildemann L, Markowski GR, Jones MC, Cass GR. Submicrometer Aerosol Mass Distributions of Emissions from Boilers, Fireplaces, Automobiles, Diesel Trucks, and Meat-Cooking Operations. Aerosol Sci Technol 1991; 14(1): 138-52. 
IGEM, IGEM/UP/19 - Design and application of interlock devices and associated systems used with gas appliance installations in commercial catering establishments. Institution of Gas Engineers and Managers (IGEM), Derbyshire, UK: 2014.

Kuehn TH, Ramsey JW, Olson BA, Rocklage JM. Characterization of cooking effluent from seven commercial kitchen appliances and representative food products (part 1). ASHRAE Trans 2009a; 115: 360-371.

Kuehn TH, Ramsey JW, Olson BA, Rocklage JM. Characterization of cooking effluent from seven commercial kitchen appliances and representative food products (part 2). ASHRAE Trans 2009b; 115: p. 126-137.

Kuehn TH, Ramsey JW, Olson BA, Rocklage JM. Characterization of effluents from additional cooking appliances. Final Report, ASHRAE 1375-RP. American Society of Heating, Refrigerating and Air-Conditioning Engineers, Inc (ASHRAE) Atlanta: 2008.

Kvasnak W, Ahmadi G, Bayer R, Gaynes M. Experimental Investigation of Dust Particle Deposition in a Turbulent Channel Flow. J Aerosol Sci 1993; 24(6): 795-815.

Lion Precision Ltd. Capacitive Sensor Operation and Optimization. http://www.lionprecision.com/techlibrary/technotes/cap-0020-sensor-theory.html (Accessed July 2013).

Liu TJ, Young MC. Eliminating Contaminants With a Piezoelectric Transducer in the Design of Low-Cost Smart Kitchen Range Hoods. IEEE Sensors Journal 2002; 2(4): 314-21.

Macrae AR, Hammond RC, Present and Future Applications of Lipases. Biotechnol Genet Eng 1995; 3: 193 217.

McDonald JD, Zielinska B, Fujita EM, Sagebiel JC, Chow JC, Watson JG. Emissions from charbroiling and grilling of chicken and beef. J Air Waste Manag Assoc 2003. 53: 185-94.

MTI Instruments Inc. Capacitance probes.

http://www.mtiinstruments.com/products/capacitancemeasurement.aspx (Accessed July 2013).

Mudie S, Essah EA, Grandison A, Felgate R. Electricity Use in the Commercial Kitchen. Int. J. Low-Carbon Tech 2013; 0, 1-9. 
Norbeck J. Standardized test kitchen and screening tools evaluation for South Coast Air Quality Management District Proposed Rule 1138. Report No. S-C95073, South Coast Air Quality Management District, El Monte, CA and the University of California CE-CERT, Riverside, CA, USA: 1997.

Omron, Laser Displacement \& Measurement Sensors. https://www.ia.omron.com/products/family/1503/ (Accessed July 2013).

Ramesh N. Grease Particle Deposition Measurements in a Kitchen Exhaust Duct for the Development of Low Cost Grease Sensors, Master of Science Dissertation in Mechanical Engineering, University of Minnesota, USA: 2010

Rim D, Novoselac A. Ventilation effectiveness as an indicator of occupant exposure to particles from indoor sources. Build Environ 2010; 45: 1214-24.

Rim D, Wallace L, Nabinger S, Persily A. Reduction of exposure to ultrafine particles by kitchen exhaust hoods: The effects of exhaust flow rates, particle size, and burner position. Sci. Total Environ 2012; 432: 350-56.

Saha S, Guha A. Experimental and computational investigation of indoor air quality inside several community kitchens in a large campus. Build Environ 2012; 52: 177-90.

Schauer JJ, Kleeman MJ, Cass GR, Simonet BRT. Measurement of emissions from air pollution sources. 1. C1 through C29 organic compounds from meat charbroiling. Environ. Sci. Technol 1999; 33: 1566-77.

Schauer JJ, Rogge WF, Hildemann LM., Mazurek MA, Cass GR. Source Apportionment of Airborne Particulate Matter Using Organic Compounds as Tracers. Atmos Environ 1996; 30(22): 3837-55.

Schrock D, Knappmiller K. RP-851 - Grease Extraction and Removal from Exhaust Air Streams of Cooking Processes Final report. American Society of Heating, Refrigerating and Air-Conditioning Engineers, Inc (ASHRAE) Atlanta: 2015.

Sippola MR, Nazaroff WW. Particle Deposition in Ventilation Ducts: Connectors, Bends and Developing Turbulent Flow, Aerosol Sci Technol 2005; 39(2): 139-50.

Swanson WJ, Loehr RC. Biofiltration: Fundamentals, Design and Operations Principles, and Applications,. J Environ. Eng 1997; 123(6): 538-46.

Swierczyna R, Sobiski R. The Effect of Makeup Air on Kitchen Hoods. ASHRAE J 2003; 6: 18-22. 
Valentini F, Diamanti A, Carbone M, Bauer EM, Palleschi, G. New cleaning strategies based on carbon nanomaterials applied to the deteriorated marble surfaces: A comparative study with enzyme based treatments. Appl. Surf. Sci 2012; 258(1): 5965-80.

van Lith C, Leson G, Michelsen R. Evaluating Design Options for Biofilters. J Air Waste Manag Assoc 1997; 47(1): 37-48.

Welch WA, Kuehn TH. Development of a Draft Method of Test For Determining Grease Removal Efficiencies RP-1151. American Society of Heating, Refrigerating and Air-Conditioning Engineers, Inc (ASHRAE) Atlanta: 2005 .

Weschler CJ, Wells JR., Poppendick D, Hubbard H, Pearce TA. Workgroup Report: Indoor Chemistry and Health. Environ Health Perspect 2006; 114: 442-6.

WHO, Air Quality Guidelines Global Update. World Health Organisation (WHO): 2005.

Winer AM, Leson G. Biofiltration: An Innovative Air Pollution Control Technology For VOC Emissions. J Air Waste Manag Assoc 1991; 41(8): 1045-54. 


\section{$1 \quad$ Figure Captions}

2 Figure 1: Average grease distribution from select appliances (plume) (adapted from Kuehn

3 et al., 2008)

4 Figure 2: Average grease distribution from select appliances (ductwork) (adapted from

$5 \quad$ Kuehn et al., 2008)

6 Figure 3: Trial site ventilation duct interior 3 weeks post manual duct clean

$7 \quad$ Figure 4: Duct plan view from above including access hatch numbers (not to scale)

$8 \quad$ Figure 5: Novel system and test duct layout (not to scale)

$9 \quad$ Figure 6: FOG deposit thickness $(\mu \mathrm{m})$

10 Figure 7: Hatch 1 pre-installation (left) and 2 months post-installation (right)

11 Figure 8: Average FOG thickness and number of meals served

12 Figure 9: DCV energy use (kWh) and savings (installed 13th October 2011)

13 Figure 10: Duct environment pre and post installation

14 Figure 11: Novel system utilities consumption 


\section{Table Titles}

16 Table 1: Summary of deposit thickness measurement methods

17 Table 2: Surface deposit limits (DTT) upon inspection (BESA, 2013)

18 Table 3: Kitchen, ductwork and system monitoring

19 Table 4: Summary of FOG reduction results and statistics

20 Table 5: FOG reduction and significance by study week

21 Table 6: Results of total viable count study

22 Table 7: Microbiological performance at the trial and reference site

23 Table 8: Summary of maximum and average temperature and relative humidity during

24 operating hour's pre and post installation 